\title{
Napawanie w regeneracji głowic cylindrowych silników okrętowych
}

\author{
Surfacing by welding in the regeneration \\ of cylinder head of ship engine
}

\section{Streszczenie}

Analizowano możliwości napawania czaszy głowicy silnika okrętowego ze staliwa niskostopowego 13CrMo4-5 nadstopem na osnowie niklu - Inconel 625 . Zbadano mikrostrukturę, skład chemiczny i fazowy napoin w funkcji parametrów napawania i liczby warstw z zastosowaniem mikroskopii świetlnej, skaningowej i dyfrakcji elektronowej oraz określono rzeczywiste parametry cyklu cieplnego napawania za pomocą analizy termowizyjnej. Określono skład chemiczny i fazowy zgorzelin wytworzonych w wyniku wysokotemperaturowego utleniania napoin.

\section{Wstęp}

Warunki pracy głowic siników okrętowych w środowisku spalin, cyklicznego działania dużych obciążeń mechanicznych i wysokich temperatur działających na czaszę głowicy są przyczynami złożonych procesów w ich warstwie wierzchniej: pękania wskutek nierównomiernego rozkładu naprężeń cieplnych, czy też zużycia erozyjnego, zużycia w wyniku korozji gazowej, niszczenia mechanicznego, np. wskutek odrywania się elementów powierzchni czołowej tłoka. Cykliczne zmiany ciśnienia i temperatury w atmosferze gazów spalinowych przyspieszają proces wysokotemperaturowej korozji gazowej i zmęczenia cieplnego obszaru wtryskiwacza mieszanki paliwowo-powietrznej głowicy silnika okrętowego.

Prof. dr hab. inż. Jerzy Nowacki - Zachodniopomorski Uniwersytet Technologiczny w Szczecinie, dr inż. Artur Wypych - Politechnika Poznańska.

\section{Abstract}

Analysis of ship motor head pad welding method of low alloyed cast steel $13 \mathrm{CrMo}-5$ by nickel matrix superalloy Inconel 625 have been presented. Microstructure, chemical and phase composition as a function of pad weIding parameters and pads number has been investigated using light, electron transmission microscopy, microanalysis, and electron diffraction. Real welding thermal cycle parameters have been estimated by thermovision analysis. Chemical and phase composition of scale generated as a result of the padding welds high temperature oxidation were determined.

Wytworzenie żaroodpornych i żarowytrzymałych napoin w najbliższym otoczeniu wtryskiwacza mieszanki paliwowo-powietrznej zdecydowanie powinno powiększyć odporność na działanie tych procesów. Zwłaszcza napawanie nadstopem na osnowie niklu obszarów wokół wtryskiwacza mieszanki paliwowej powinno zapewnić

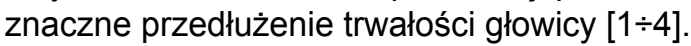

Napawanie wielkogabarytowych elementów, jakimi są głowice siników okrętowych, wymaga specjalnych zabiegów technologicznych. Proces napawania głowicy silnika okrętowego, której masa może wynosić $5000 \div 8000 \mathrm{~kg}$, może być realizowany na wyspecjalizowanym stanowisku spawalniczym, najlepiej wyposażonym w robot spawalniczy i odchylany obrotnik o bezpiecznym udźwigu odpowiednim dla masy pojedynczej głowicy. Oba elementy powinny być sprzężone przez jeden układ sterowania, a procedura napawania winna ograniczać konieczność przebywania personelu bezpośrednio przy stanowisku spawalniczym $[5,6]$.

Duża masa głowicy wymaga długiego czasu podgrzewania przed spawaniem wynoszącego $6 \div 10 \mathrm{~h}$ 
przy braku możliwości jego skrócenia w wyniku zwiększenia intensywności nagrzewania, ze względu na ryzyko wprowadzenia lokalnych przemian. Za pomocą płaszczy termicznych z podgrzewaczami można zapewnić warunki utrzymania wymaganej temperatury podgrzewania wstępnego do chwili rozpoczęcia napawania i utrzymanie jej w wyniku przykrycia matami termoizolującymi.

\section{Próby napawania warstwy wierzchniej głowic silników okrętowych}

Analizowano możliwości napawania czaszy głowicy silnika okrętowego wykonanej ze staliwa chromowo - molibdenowego 13CrMo4-5 o składzie chemicznym: C - 0,16\%, Mn - 0,645\%, Si - 0,19\%, P - 0,012\%, $\mathrm{S}-0,015 \%, \mathrm{Cr}-0,94 \%$, Mo - 0,47\%, Cu - 0,19\%, $\mathrm{Al}-0,019 \%$ drutem pełnym o średnicy $1,2 \mathrm{~mm}$ z żaroodpornego nadstopu na osnowie niklu Inconel 625 o składzie chemicznym: $\mathrm{Ni}$ - osnowa, $\mathrm{Cr}-22 \%$, Mo - 9\%, $\mathrm{Nb}-3,3 \%, \mathrm{Fe}-1 \%, \mathrm{Si}-0,2 \%, \mathrm{Mn}-0,2 \%, \mathrm{C}-0,02 \%$.

Zastosowanie zróżnicowanych parametrów napawania Inconelu 625 na podłożu staliwa 13CrMo4-5 uwarunkowało wystąpienie różnych właściwości wytworzonych napoin. Podstawowym parametrem określającym te różnice jest zawartość w napoinach pierwiastków pochodzących z podłoża. Udział materiału podłoża jest określany przede wszystkim zawartością żelaza w napoinie. Takie uproszczenie jest możliwe, ponieważ żelazo jest głównym składnikiem materiału podłoża. Zwiększanie zawartości pierwiastków pochodzących z podłoża powoduje obniżanie odporności na warunki pracy napoiny $[7,8]$. Celowy jest więc dobór warunków napawania zapewniających jak najmniejszy udział składników stopowych podłoża w napoinie.

W celu określenia parametrów zapewniających najlepsze właściwości napoin wykonano kilka serii prób z zastosowaniem zróżnicowanych parametrów napawania. Zastosowano trzy poziomy ilości wprowadzonego ciepła napawania: $Q=300,620,2100 \mathrm{~J} / \mathrm{mm}$ i atmosferę argonu. Temperatura podgrzewania wstępnego wynosiła $250^{\circ} \mathrm{C}$. Zastosowanie wymienionych warunków napawania wprowadziło znaczące zmiany geometrii, składu chemicznego napoin oraz szerokości strefy wpływu ciepła w materiale podłoża.

Wytworzono napoiny wielowarstwowe. W napawaniu wielowarstwowym materiałem podłoża dla kolejnej napoiny jest poprzednia warstwa napoiny, stąd można się spodziewać znacznej redukcji pierwiastków pochodzących z podłoża w kolejnych warstwach napoin. Dla wszystkich ilości wprowadzonego ciepła napawania wytworzono napoiny trójwarstwowe. Jedynie dla $Q=300 \mathrm{~J} / \mathrm{mm}$ wytworzono napoiny czterowarstwowe. Zwiększona liczba warstw podczas napawania z ilością wprowadzonego ciepła napawania $Q=300 \mathrm{~J} / \mathrm{mm}$ spowodowana była koniecznością wypełnienia rowka [7].

\section{Cykl ciepIny napawania}

Warunki kontroli cyklu cieplnego napawania wielkogabarytowych elementów uzasadniają zastosowanie w pomiarach bezstykowej metody termowizyjnej, co umożliwia obserwację rozkładu temperatury w całej

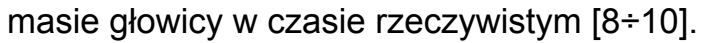

Termowizyjną analizę cyklu cieplnego napawania wykorzystano do wyznaczenia czasów pozostawania złącza w zakresie temperatur przemian strukturalnych przy parametrach napawania $Q=620 \mathrm{~J} / \mathrm{mm}$, Ar oraz $Q=2100 \mathrm{~J} / \mathrm{mm}$, Ar. Na podstawie danych literaturowych i analizy wykresów CTP zastosowanych materiałów rodzimego i dodatkowego określono, że dla materiału podłoża 13CrMo4-5 jest to temperatura zawarta w przedziale $800 \div 500^{\circ} \mathrm{C}$, a dla Inconelu 625 - temperatury $1100 \div 600^{\circ} \mathrm{C}$. Wyznaczony na podstawie analizy termowizyjnej czas $t_{8-5}$ materiału podłoża 13CrMo4-5 wynosi 1,4 s dla napawania gdzie $Q=620 \mathrm{~J} / \mathrm{mm}$, atmosfera - argon, a dla napawania gdzie $Q=2100 \mathrm{~J} / \mathrm{mm}$, atmosfera - argon, czas $t_{8-5}$ wynosi 4,7 s. (rys. $1 \div 3$ ). Ponadto wyznaczony termowizyjnie cykl cieplny napawania umożliwia oszacowanie czasu oczekiwania na uzyskanie temperatury międzyściegowej $250 \div 260^{\circ} \mathrm{C}$.

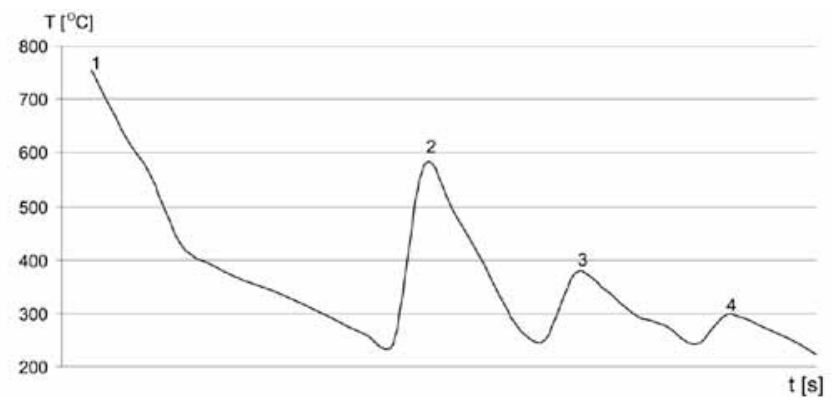

Rys. 1. Krzywa przebiegu chłodzenia podłoża dla napoiny o parametrach $Q=2100 \mathrm{~J} / \mathrm{mm}$, atmosfera - argon; 1 $\div 4$ - czasy wykonania kolejnych napoin $[8 \div 10]$

Fig. 1. The substrate cooling curve for padding weld with process parameters $Q=2100 \mathrm{~J} / \mathrm{mm}$, the atmosphere - argon, points $1 \div 4$ - the

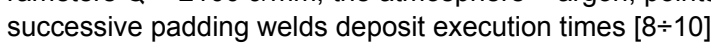

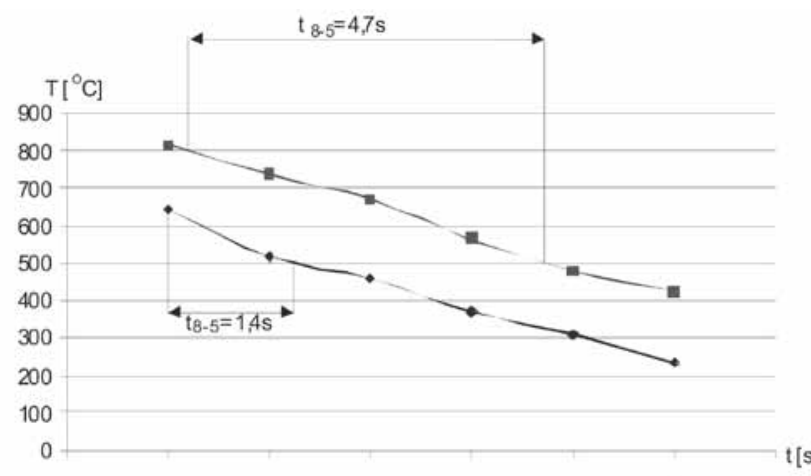

- $\mathrm{Q}=620 \mathrm{~J} / \mathrm{mm} \rightarrow-\mathrm{Q}=2100 \mathrm{~J} / \mathrm{mm}$

Rys. 2. Czas $t_{8-5}$ chłodzenia w zakresie przemian fazowych materiału rodzimego - staliwa 13CrMo4-5, ilość wprowadzonego ciepła napawania: $Q=620 \mathrm{~J} / \mathrm{mm}$ i $Q=2100 \mathrm{~J} / \mathrm{mm}, \operatorname{Ar}[8 \div 10]$

Fig. 2. Cooling time $t_{8-5}$ in the base metal phase transitions - steel $13 \mathrm{CrMo} 4-5$, the amount of pad welding heat input: $Q=620 \mathrm{~J} / \mathrm{mm}$ and $Q=2100 \mathrm{~J} / \mathrm{mm}, \operatorname{Ar}[8 \div 10]$ 


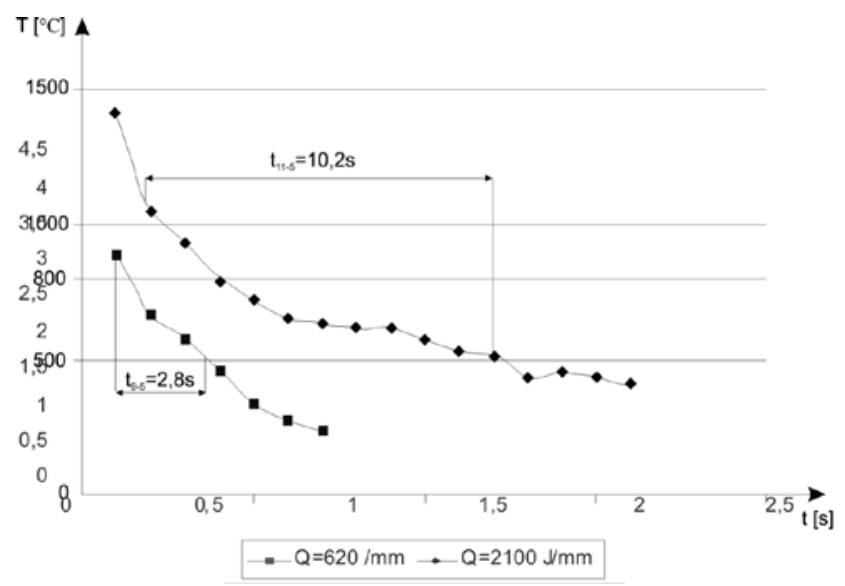

Rys. 3. Czas $t_{11-5}$ chłodzenia w zakresie przemian fazowych napoiny - Inconel 625 , ilość wprowadzonego ciepła napawania: $Q=620 \mathrm{~J} / \mathrm{mm}$ i $Q=2100 \mathrm{~J} / \mathrm{mm}, \operatorname{Ar}[8 \div 10]$

Fig. 3. Cooling time $t_{11-5}$ in the padding weld phase transitions - Inconel 625 , the amount of pad welding heat input: $Q=620 \mathrm{~J} / \mathrm{mm}$ and $Q=2100 \mathrm{~J} / \mathrm{mm}, \operatorname{Ar}[8 \div 10]$

\section{Mikrostruktura napoin}

Mikrostrukturę warstw charakteryzuje występowanie typowego dla napawania dendrytycznego układu roztworu stałego y obecnego zarówno po napawaniu jedno-, jak i wielowarstwowym (rys. 4). W napoinach zidentyfikowano dodatkowo $w$ wyniku analizy XRD

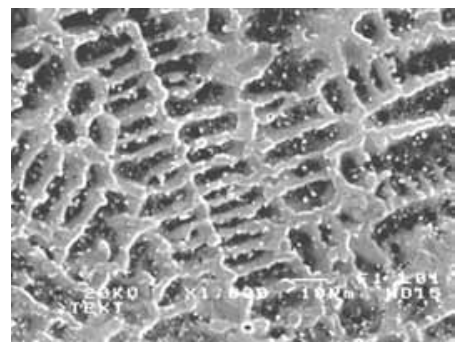

Rys. 4. Mikrostruktura napoiny trójwarstwowej, wytworzonej z ilością wprowadzonego ciepła $Q=2100 \mathrm{~J} / \mathrm{mm}$ w atmosferze argonu; dendryty fazy y powstałe $w$ wyniku krystalizacji; próbki pobrano $z$ głębokości $2 \mathrm{~mm}$ pod powierzchnią lica

Fig. 4. Three-layer padding weld microstructure produced with the amount of heat input $Q=2100 \mathrm{~J} / \mathrm{mm}$ in the argon atmosphere; dendrites $y$ phase formed by crystallization, sampled from a depth of $2 \mathrm{~mm}$ below the face

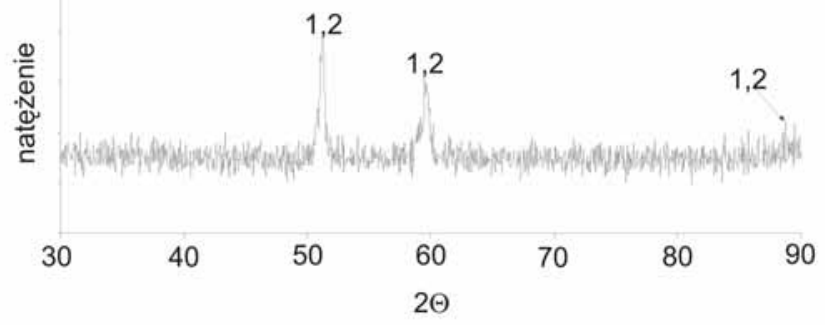

Rys. 5. Dyfraktogram napoiny trójwarstwowej wytworzonej z ilością wprowadzonego ciepła $Q=2100 \mathrm{~J} / \mathrm{mm}$ w atmosferze argonu; $1-\mathrm{CrFeNi}, 2-\mathrm{FeNi}$

Fig. 5. Diffraction pattern of three-layer padding weld produced with the amount of heat input $Q=2100 \mathrm{~J} / \mathrm{mm}$ in an argon atmosphere, $1-\mathrm{CrFeNi}, 2-\mathrm{FeNi}$

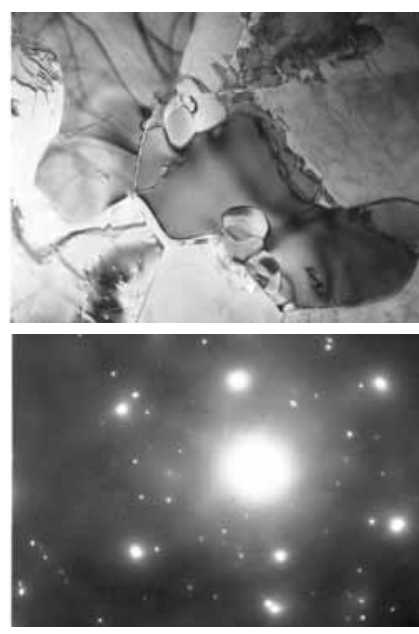

Rys. 6. Widok i dyfrakcja elektronowa węglika $\mathrm{M}_{23} \mathrm{C}_{6}$ na tle osnowy $\mathrm{Y}$ w napoinie trójwarstwowej, wytworzonej $z$ ilością wprowadzonego ciepła $Q=2100 \mathrm{~J} / \mathrm{mm}$ w atmosferze argonu, pow. $27500 x$

Fig. 6. View and electron diffraction of $\mathrm{M}_{23} \mathrm{C}_{6}$ carbide in the matrix $\mathrm{Y}$ background in three-layer padding weld, prepared with the amount of heat input $\mathrm{Q}=2100 \mathrm{~J} / \mathrm{mm}$ in argon atmo[010] $\mathrm{m}_{\mathrm{s}}$. sphere, magn. $27500 x$

obecność roztworów stałych CrFeNi oraz FeNi występujących w każdym z wariantów napawania (rys. 5). Niewielki, niewykrywalny metodą XRD, udział węglika $\mathrm{M}_{23} \mathrm{C}_{6}$ w napoinie potwierdzono w wyniku dyfrakcji elektronowej (rys. 6).

\section{Skład chemiczny napoin}

Badania składu chemicznego napoin wykonano metodą mikroanalizy rentgenowskiej punktowej. Zawartość żelaza, pochodzącego z materiału rodzimego, na powierzchni lica napoin trójwarstwowych wykonanych w atmosferze argonu, wynosi $0,66 \%$ wagowych dla napoin o parametrach $Q=620 \mathrm{~J} / \mathrm{mm}$ oraz wynosi $2,29 \%$ wag. dla napoin o parametrach $Q=2100 \mathrm{~J} / \mathrm{mm}$. Podobne zależności wykazują napoiny wykonane $\mathrm{w}$ atmosferze dwutlenku węgla. Udział żelaza w napoinach zwiększa się ze wzrostem ilości wprowadzonego ciepła napawania (tabl. I).

Tablica I. Skład chemiczny napoin jedno- i wielowarstwowych Table I. Chemical composition of one- and multilayer padding welds

\begin{tabular}{|c|c|c|c|c|c|c|}
\hline \multirow{3}{*}{ Składnik } & \multicolumn{6}{|c|}{ Ilość wprowadzonego ciepła napawania Q, J/mm } \\
\cline { 2 - 7 } & 300 & 300 & 620 & 620 & 2100 & 2100 \\
\cline { 2 - 7 } & \multicolumn{6}{|c|}{ Nr warstwy w napoinie } \\
\cline { 2 - 7 } & $\mathrm{I}$ & $\mathrm{IV}$ & $\mathrm{I}$ & $\mathrm{III}$ & $\mathrm{I}$ & III \\
\cline { 2 - 7 } & \multicolumn{7}{|c|}{ Śdnia zawartość składnika w warstwie, \% wag. } \\
\hline $\mathrm{Cr}$ & 23,9 & 23,8 & 18,5 & 23,3 & 19,7 & 23,6 \\
\hline $\mathrm{Fe}$ & 2,3 & 0,2 & 23,4 & 0,7 & 17,4 & 2,3 \\
\hline $\mathrm{Ni}$ & 56,3 & 58,3 & 40,8 & 55,9 & 44,2 & 55,8 \\
\hline $\mathrm{Si}$ & 0,1 & 0,1 & 0,2 & 0,1 & 0,2 & 0,1 \\
\hline $\mathrm{Ti}$ & 0,1 & 0,1 & 0,1 & 0,2 & 0,1 & 0,1 \\
\hline $\mathrm{Mo}$ & 13,8 & 14,1 & 16,9 & 15,3 & 13,9 & 14,2 \\
\hline $\mathrm{Nb}$ & 3,4 & 3,3 & $<0,1$ & 4,3 & 4,4 & 3,9 \\
\hline
\end{tabular}


Napawanie z najmniejsza ilością wprowadzonego ciepła napawania, $Q=300 \mathrm{~J} / \mathrm{mm}$ powoduje udział żelaza - głównego składnika podłoża w napoinie na średnim poziomie 7\%. Napawanie z największą ilością wprowadzonego ciepła napawania, $Q=2100 \mathrm{~J} / \mathrm{mm}$, powoduje udział żelaza w napoinie na średnim poziomie $21 \%$ i jest on mniejszy niż w napoinach z $Q=630 \mathrm{~J} / \mathrm{mm}$ gdzie wartość ta wynosi $28 \%$. Zmniejszony udział podłoża w napoinie wysokoenergetycznej wynika z dużej prędkości podawania drutu podczas napawania i wywołanej tym dużej wysokości nadlewu.

\section{Wyniki wysokotemperaturowego utleniania napoin}

Badania wysokotemperaturowego utleniania napoin wykonano metodą termowagową w zakresie temperatury $850 \div 930^{\circ} \mathrm{C}$ w czasie $60 \mathrm{~h}$. Najmniejszą odpornością na wysokotemperaturowe utlenianie wykazał się w tych warunkach materiał podłoża, który z dużą szybkością pokrywał się warstwą zgorzeliny tlenkowej. Grubość warstwy zgorzeliny wynosiła $410 \mu \mathrm{m}$ po 8 h ekspozycji w warunkach utleniania.

Największą odpornością na wysokotemperaturowe utlenianie charakteryzował się materiał dodatkowy - Inconel 625.

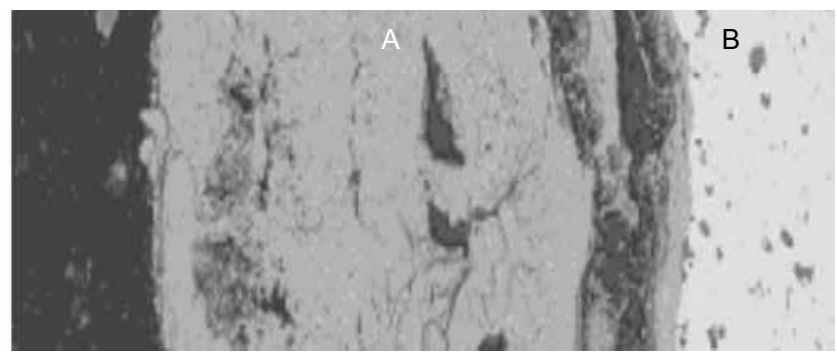

Rys. 7. Obraz EDS zgorzeliny powstałej na powierzchni staliwa 13CrMo4-5, grubość zgorzeliny - $410 \mu \mathrm{m}$; A - zgorzelina, B - podłoże

Fig. 7. EDS image of scale formed on the surface of steel 13CrMo4-5, the thickness of the scale $-410 \mu \mathrm{m} ; \mathrm{A}$ scale, $B$ - substrate

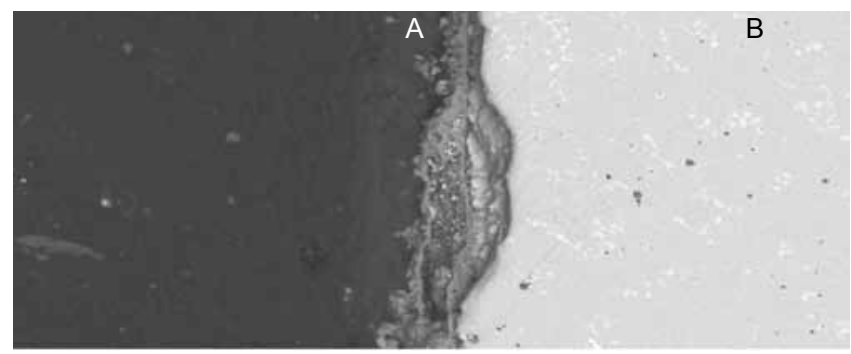

Rys. 8. Obraz EDS zgorzeliny na powierzchni lica napoiny trójwarstwowej wytworzonej $z$ ilością wprowadzonego ciepła $Q=2100 \mathrm{~J} / \mathrm{mm}$, grubość zgorzeliny - $5 \mu \mathrm{m} ; \mathrm{A}$ - zgorzelina, $B$ - podłoże Fig. 8. EDS image scale on the surface of the three-layer padding weld face formed with heat input $Q=2100 \mathrm{~J} / \mathrm{mm}$, scale thickness $-5 \mathrm{~mm}$; A - scale, B - substrate
Tablica II. Względna zmiana masy próbek podczas utleniania w zakresie temperatury $850 \div 930^{\circ} \mathrm{C}$ w czasie $60 \mathrm{~h}$

Table II. Relative weight change of samples during oxidation in the temperature range $850 \div 930^{\circ} \mathrm{C}$ during 60 hours

\begin{tabular}{|l|l|c|}
\hline $\begin{array}{c}\text { Ilość wprowadzonego } \\
\text { ciepła napawania } Q\end{array}$ & $\begin{array}{c}\text { Miejsce pobrania } \\
\text { próbki }\end{array}$ & $\begin{array}{c}\text { Przyrost masy, } \\
\mathrm{mg} / \mathrm{mm}^{2}\end{array}$ \\
\hline $\begin{array}{l}\text { 13CrMo4-5 - materiał ro- } \\
\text { dzimy przed napawaniem }\end{array}$ & $\begin{array}{l}\text { powierzchnia } \\
\text { głowicy silnika }\end{array}$ & $0,1700(\mathrm{po} 8 \mathrm{~h})$ \\
\hline $\begin{array}{l}\text { Inconel } 625-\text { materiał do- } \\
\text { datkowy przed napawaniem }\end{array}$ & drut elektrodowy & 0,0031 \\
\hline$Q=2100 \mathrm{~J} / \mathrm{mm}$ & $\begin{array}{l}\text { lico napoiny } \\
\text { trójwarstwowej }\end{array}$ & 0,0069 \\
\hline$Q=620 \mathrm{~J} / \mathrm{mm}$ & $\begin{array}{l}\text { lico napoiny } \\
\text { trójwarstwowej }\end{array}$ & 0,0048 \\
\hline$Q=620 \mathrm{~J} / \mathrm{mm}$ & $\begin{array}{l}\text { lico napoiny } \\
\text { jednowarstwowej }\end{array}$ & 0,2205 \\
\hline
\end{tabular}

Odporność na wysokotemperaturowe utlenianie napoin była mniejsza niż materiału dodatkowego i znacznie większa niż materiału podłoża (tabl. II).

Wytworzenie napoiny wielowarstwowej zdecydowanie zwiększa odporność na utlenianie, czego efektem jest wytworzona zgorzelina o grubości $5 \mu \mathrm{m}$ w czasie ekspozycji wynoszącym 60 h (rys. 7, 8, tabl. II).

\section{Skład chemiczny i struktura zgorzelin}

Badania składu chemicznego zgorzelin wykonano metodą mikroanalizy rentgenowskiej punktowej. Skład chemiczny zgorzelin wykazuje największy udział chromu niezależnie od ilości wprowadzonego ciepła napawania (tabl. III).

Rentgenowska analiza strukturalna utworzonych zgorzelin wykazała, że składnikiem zgorzelin utworzonych na napoinach wykonanych w osłonie argonu, jest związek $\mathrm{Cr}_{2} \mathrm{O}_{3}$ oraz spinel $\mathrm{NiCr}_{2} \mathrm{O}_{4}$ (rys. 9). Dobra przyczepność zgorzeliny do podłoża zapewnia dobrą ochronę antykorozyjną. W przypadku żadnej napoiny zgorzelina nie odpadła od utlenianej powierzchni. Odpadnięcie zgorzeliny od podłoża nastąpiło jedynie w przypadku utleniania materiału podłoża.

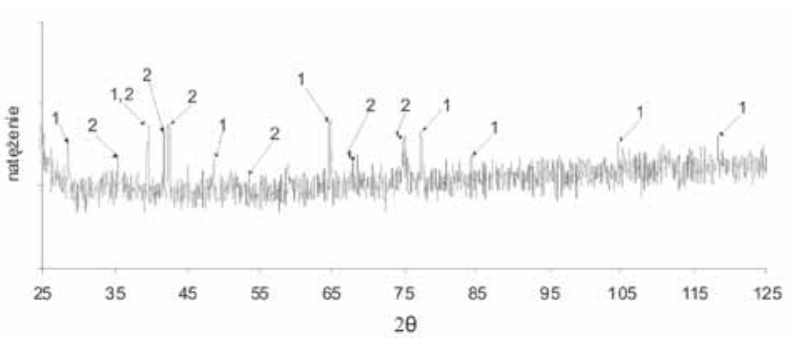

Rys. 9. Dyfraktogram zgorzeliny utworzonej na powierzchni lica napoiny trójwarstwowej wytworzonej z ilością wprowadzonego ciepła $\mathrm{Q}=2100 \mathrm{~J} / \mathrm{mm}$ w atmosferze argonu; $1-\mathrm{Cr}_{2} \mathrm{O}_{3}, 2-\mathrm{NiCr}_{2} \mathrm{O}_{4}$

Fig. 9. Diffraction pattern of the scale formed on the surface of three-layer padding weld face produced with the amount of heat input $\mathrm{Q}=2100 \mathrm{~J} / \mathrm{mm}$ in the argon atmosphere; $1-\mathrm{Cr}_{2} \mathrm{O}_{3}, 2-\mathrm{NiCr}_{2} \mathrm{O}_{4}$ 
Tablica III. Skład chemiczny zgorzelin powstałych na materiale rodzimym, materiale dodatkowym i na powierzchni napoin jedno- i wielowarstwowych

Table III. Chemical composition of scale formed on the base material, the filler material and on the surface of single-and multilayer padding welds

\begin{tabular}{|c|c|c|c|c|c|}
\hline \multirow{6}{*}{ Składnik } & \multirow{6}{*}{$\begin{array}{c}\text { Materiał rodzimy } \\
\text { przed napawaniem }\end{array}$} & \multirow{6}{*}{$\begin{array}{l}\text { Materiał dodatkowy } \\
\text { przed napawaniem }\end{array}$} & \multicolumn{3}{|c|}{ Napoina } \\
\hline & & & \multicolumn{3}{|c|}{ Ilość wprowadzonego ciepła napawania $\mathrm{Q}, \mathrm{J} / \mathrm{mm}$} \\
\hline & & & 620 & 620 & 2100 \\
\hline & & & \multicolumn{3}{|c|}{ nr warstwy w napoinie } \\
\hline & & & 1 & III & III \\
\hline & & & \multicolumn{3}{|c|}{ średnia zawartość składnika w warstwie, \% wag. } \\
\hline $\mathrm{Cr}$ & - & 69,7 & 72,7 & 77,1 & 63,7 \\
\hline $\mathrm{Fe}$ & 84,5 & 0,3 & 2,9 & 0,1 & 0,7 \\
\hline $\mathrm{Ni}$ & - & 5,4 & 1,2 & 1,3 & 6,0 \\
\hline $\mathrm{O}$ & 14,9 & 19,3 & 14,6 & 18,9 & 17,5 \\
\hline Si & 0,2 & 0,2 & 0,2 & 0,2 & 0,2 \\
\hline $\mathrm{Ti}$ & - & 1,3 & 0,3 & 0,1 & 0,2 \\
\hline Mo & - & 0,8 & 0,4 & $<0,1$ & 1,2 \\
\hline $\mathrm{Nb}$ & - & 0,6 & 1,3 & $<0,1$ & 6,4 \\
\hline
\end{tabular}

\section{Wnioski}

Zastosowanie napawania wielowarstwowego zapewnia zmniejszenie ilości pierwiastków pochodzących z materiału rodzimego, ponieważ dla każdej następnej warstwy napoiny podłożem jest poprzednia.

Odporność na korozję gazową napoin z nadstopu Inconel 625 na stali 13 CrMo4 wzrasta ze wzrostem liczby ściegów w wyniku zmniejszania się w kolejnych ściegach zawartości pierwiastków sprzyjających korozji, pochodzących z materiału podłoża.
Zgorzelina zawiera głównie pierwiastki takie jak żelazo, nikiel, tlen i w zdecydowanie największej ilości chrom.

Zgorzelina utworzona na napoinie w wyniku procesu utleniania składa się $\mathrm{z}$ tlenków $\mathrm{Cr}_{2} \mathrm{O}_{3}$, oraz $\mathrm{NiCr}_{2} \mathrm{O}_{4}$.

Największą odpornością na wysokotemperaturowe utlenianie cechują się napoiny wielowarstwowe wykonane $z$ małą ilością wprowadzonego ciepła napawania $-Q=620 \mathrm{~J} / \mathrm{mm}$.

\section{Literatura}

[1] Cho S., Hur J., Seo C., Park S.: High temperature corrosion of superalloys in a molten salt under an oxidizing atmosphere, Journal of Alloys and Compounds, 2008 vol. 452, no. 1 , pp. 11-15.

[2] Jarosiński, J.; Błaszczyk, M., Tasak, E., Napawanie stali stosowanych w energetyce stopami na osnowie niklu, Przegląd Spawalnictwa, 1/2007, s. 30-33.

[3] Kohler M., Effect of the elevated-temperature-precipitation in Alloy 625 properties and microstructure, Superalloys 718 , 625 and Various Derivatives, 1991, s. 363-374.

[4] Shankar Vani: Bhanu Sankara Rao, K. Mannan, S.L., Microstructure and mechanical properties of Inconel 625 superalloy, Journal of Nuclear Materials, vol. 288, issue 2-3 February, 2001, s. 222-232.

[5] Nowacki J., Wypych A., Problemy zużycia i modyfikacji warstwy wierzchniej głowic silników okrętowych, Przegląd Spawalnictwa 7/2010, s. 2-7.
[6] Nowacki J., Wypych A., Mikrostruktura i odporność na wysokotemperaturowe utlenianie napoin nadstopu Inconel 625 na stali niskostopowej - Biuletyn Instytutu Spawalnictwa 5/2010, s. 84-87.

[7] Nowacki J., Wypych A., Zrobotyzowane napawanie stali niestopowych nadstopami niklu, Biuletyn Instytutu Spawalnictwa w Gliwicach, 5/2005, s. 58-65.

[8] Nowacki J., Wypych A., Termowizyjne badania cyklu cieplnego napawania stali niskostopowej żaroodpornym nadstopem na osnowie niklu, Biuletyn Instytutu Spawalnictwa 5/2008, s. 146-151.

[9] Nowacki J., Wypych A., Application of thermovision method to welding thermal cycle analysis, Journal of Achievements in Materials and Manufacturing Engineering - vol. 40, issue 2, June 2010, s. 131-137.

[10] Nowacki J., Wypych A., Ocena cyklu cieplnego napawania stali $13 \mathrm{CrMo4}-5$ nadstopem Inconel 625 metodą termowizyjną, Przegląd Spawalnictwa 12/2007, s. 3-7. 